\title{
Understanding a Man-Made Epidemic The Relation between Historical Asbestos Consumption and Mesothelio- ma Mortality in Belgium
}

\section{Laura Van den Borre and Patrick Deboosere*}

\author{
TSEG $14(4): 116-138$ \\ DOI: $10.1835^{2} /$ TSEG.989
}

\begin{abstract}
This article discusses (i) the history of asbestos use between 1948 and 2001; (ii) the development of the current epidemic of mesothelioma deaths (19692014); and (iii) reasons for the belated government intervention in Belgium. Belgium imported over two billion tonnes of raw asbestos from 1948 until 1998. The current peak in male mesothelioma deaths corresponds to the expansion of the asbestos industry 40 years earlier. Reasons for the delayed government intervention include long latency periods of asbestos-related diseases, faulty communication about health risks, a strong asbestos lobby and an ambivalent government. Public health was sacrificed in favour of industrial development, economic advancement and political gain. The Belgian case further underlines the need for a global ban on asbestos.
\end{abstract}

\section{Introduction}

Belgium became a major international supplier of asbestos products in the aftermath of the Second World War. ${ }^{1}$ The country had the highest asbestos consumption level per capita in the world during the 196 os. $^{2}$ Despite scientific evidence of the fatal health effects since the 1920s, Belgium continued to manufacture asbestos products on a large scale until a formal ban in 1998. Asbestos remains a major public health con-

\footnotetext{
* We thank Dr Tom Douglas for his thoughtful comments and suggestions. Research Foundation-Flanders (FWO) and the research council of Vrije Universiteit Brussel provided financial support.

1 R.L. Virta, Worldwide asbestos supply and consumption Trends from 1900 through 2003 (Reston VA 2006) 1-80, 13-14.

2 T.S. Nawrot et al., 'Belgium: Historical champion in asbestos consumption', Lancet 369 (2007) 1692.
} 
cern due to the rising disease burden and the large quantity of fibres still in place.

Malignant mesothelioma - a disease caused almost entirely by asbestos exposure - was extremely rare during the first half of the twentieth century. As a result of extensive industrial asbestos use, incidence and mortality rates have increased dramatically around the globe over recent decades. ${ }^{3}$ Mesothelioma causes an estimated 43,000 deaths worldwide every year. ${ }^{4}$ Belgium is positioned fourth in the global mesothelioma epidemic. ${ }^{5}$ Recent projections for six European countries indicate that mesothelioma deaths will peak in de coming decade. ${ }^{6}$ It is widely recognized that knowledge of manufacturing processes, protective measures and exposure circumstances is imperative to understand trends in asbestos-related diseases.

However, the historical origins of the asbestos problem have been scarcely investigated for Belgium. The lack of exposure data inhibits asbestos research as much of the available data is destroyed, missing or scattered. ${ }^{7}$ Many countries, including the Netherlands, have made considerable research efforts to overcome this information gap. Expert panels have been used to construct a Dutch asbestos map with known asbestos-related industries and occupations. ${ }^{8} \mathrm{~A}$ job-exposure matrix has been developed with the available information. ${ }^{9}$ Our previous research

3 V. Delgermaa et al., 'Global mesothelioma deaths reported to the World Health Organization between 1994 and 2008', Bulletin of the World Health Organization 89 (2011) 716-724C; Claudio Bianchi and Tommaso Bianchi, 'Global mesothelioma epidemic: Trend and features', Indian Journal of Occupational and Environmental Medicine 18 (2014) 82-88, DOI: $10.4103 / 0019-5278.146897$.

4 Timothy Driscoll et al., 'The global burden of disease due to Eccupational carcinogens', American Journal of Industrial Medicine 48 (2005) 419-431, 425. DOI: 10.1002/ajim.20209.

5 Laura Van den Borre and Patrick Deboosere, 'Asbestos in Belgium: An underestimated health risk. The evolution of mesothelioma mortality rates (1969-2009)', International Journal of Occupational and Environmental Health 20 (2014) 134-140, DOI: 10.1179/2049396714Y.oooooooo58.

6 Andrew Darnton, Clare Gilham and Julian Peto, 'Epidemiology of malignant pleural mesothelioma in Europe', in: Malignant pleural mesothelioma: Present status and future directions (Sharjah 2016) 33-52. 7 Laura Van den Borre and Patrick Deboosere, 'The asbestos industry in Belgium (1945-2001) Interface Demography Working Paper 2016-3', 3-4 (Vakgroep soci Vrije Universiteit Brussel 2016) http:// www.vub.ac.be/demography/wp-content/uploads/2016/o2/IDWP2016-2.pdf (accessed 17 August 2017); Eun-Kee Park et al., 'Global magnitude of reported and unreported mesothelioma', Environ Health Perspect 119 (2011) 514-518, 517 .

8 'Asbestkaart', Historisch onderzoek Asbestgebruik en Methode Asbest-kansenkaart, Asbest in Kaart (2006), https://www.asbestkaart.nl/asbestkaart.html (accessed 12 July 2017); Alex Burdorf and Paul Swuste, 'An expert system for the evaluation of historical asbestos exposure as diagnostic criterion in asbestos-related diseases', The Annals of Occupational Hygiene 43 (1999) 57-66, Dor: 10.1093/annhyg/43.1.57.

9 Paul Swuste, Mohssine Dahhan and Alex Burdorf, 'Linking expert judgement and trends in occupa- 
already provides a starting point for historical analyses by presenting an overview of asbestos industries and the available information on specific manufacturers. ${ }^{10}$ The previous findings were based on the Us Geological Survey, which outlines international asbestos trade statistics in 10- and 5-year time intervals. ${ }^{11}$ For the current study, we obtained the original data source to investigate the historical import and export of asbestos fibres in greater detail. The present article is the first to present annual production records on asbestos trade for Belgium.

The article consists of three parts. First, we provide an overview of the rise and fall of the Belgian asbestos industry from 1948 to 1998 using unique annual production records. Second, the development of the current epidemic of mesothelioma deaths (1969-2014) is reviewed in light of historical asbestos consumption. Third, we pursue one of the most important unanswered questions in the history of asbestos in Belgium: why was the government so late to intervene?

\section{History of asbestos use}

Asbestos use dates back to ancient times. The term refers to a group of six naturally occurring minerals and derives from the Greek word ' $\alpha \sigma \beta \varepsilon \sigma \tau о \varsigma$ ' meaning inextinguishable. The heat-resistant and durable characteristics of asbestos were already known in 3,500 BC as exemplified by remnants of Finnish asbestos pottery. ${ }^{12}$ The material was rediscovered in the course of the industrialization in the late 180os. Asbestos became a popular component in numerous industries because of its strength, bio-resistance and low-production costs. The fibrous structure allows minerals to be spun into textile or mixed with resin, cement or plastics. ${ }^{13}$ Over 3,000 different applications of asbestos have been patented including brake linings, roofing, insulation and cigarette filters.

tional exposure into a job-exposure matrix for historical exposure to asbestos in the Netherlands', The Annals of Occupational Hygiene 52 (2008) 397-403, DOI: 10.1093/annhyg/menozo.

10 Van den Borre and Deboosere, 'The asbestos industry in Belgium (1945-2001)'.

11 Virta, Worldwide asbestos supply, 35-79.

12 M. Lavento and S. Hornytzkyj, 'On asbestos used as temper in Finnish subneolithic, neolithic and early metal period pottery', Fennoscandia Archaeologica XII (1995) 71-75.

13 P.W.J. Bartrip, 'History of asbestos related disease', Postgraduate Medical Journal 80 (2004) 72, DoI: $10.1136 /$ pmj.2003.012526. 
Belgium has no natural deposits of asbestos. All minerals were imported from the beginnings of the Belgian asbestos industries in the late nineteenth century. ${ }^{14}$ Asbestos products manufacturing experienced its first powerful impetus with the need for rapid reconstruction after the First World War. After a brief period of high output, the Second World War caused manufacturing to grind to a halt. ${ }^{15}$ How asbestos transitioned from magic mineral to a major public health concern is demonstrated in the annual import and export records.

For this study, historical consumption data were derived from the annual statistics on foreign trade from 1948 to 1998 , with the exception of unavailable data in $1995 .{ }^{16}$ Import and export information on raw asbestos and asbestos-containing products were consulted. Data prior to 1960 only include information on raw asbestos coded as $194 \mathrm{~b}$ Amiante or Asbest in the national nomenclature of goods. After 196o, the nomenclature of commodities by the World Customs Organization include raw asbestos (2524) and asbestos containing products $(68.12$ and 68.13; since 1988 also 68.11). Because of an economic partnership established in 1921, records for Belgium and Luxembourg were combined. ${ }^{17}$ We established in previous research that the vast majority of imported asbestos was intended for Belgian asbestos industries..$^{18}$ Apparent consumption is calculated as import minus export for Belgium and Luxemburg. Asbestos consumption per capita is calculated using population data for the period 1950-1998 from the wHO Mortality database. ${ }^{19}$ The dataset did not include population information for 1948 and 1949. As a result, data were derived from the annual statistics for Belgium. ${ }^{20}$

Figure 1 shows import data of raw asbestos for Belgium and Luxembourg in 1948-1998. A total amount of 2,015,225.9 tonnes asbestos was

\footnotetext{
14 Virta, Worldwide asbestos supply, 2-3.

15 Van den Borre and Deboosere, 'The asbestos industry in Belgium (1945-2001)', 5-6.

16 National Institute for Statistics, 'Bulletin mensuel du commerce de l'union economique Belgo-Luxembourgeoise avec Les Pays Etrangers (1948-1994; 1996-1998)', (Bruxelles: Ministère des affaires économiques, n.d.) Quetelet library.

17 Eduard Somers, 'Belgium-Luxembourg economic union', Max-Planck Encyclopedia of Public International Law 1 (2012) 869, DOI: 10.1017/CBO9781107415324.004.

18 Van den Borre and Deboosere, 'The asbestos industry in Belgium (1945-2001)', 5.

19 World Health Organization (wHO) global health observatory, wHO mortality database: World Health Organization statistical information system (WHOSIS n.d.) http://www.who.int/healthinfo/statistics/ mortality_rawdata/en/index.html (accessed 4 May 2015).

20 National Institute for Statistics, Annuaire statistique de La Belgique-Statistisch jaarboek van België, 1950 (accessed 4 July 2017).
} 
Figure 1 Import of raw asbestos in tonnes in Belgium and Luxembourg (19481998), total and by selected countries of origin

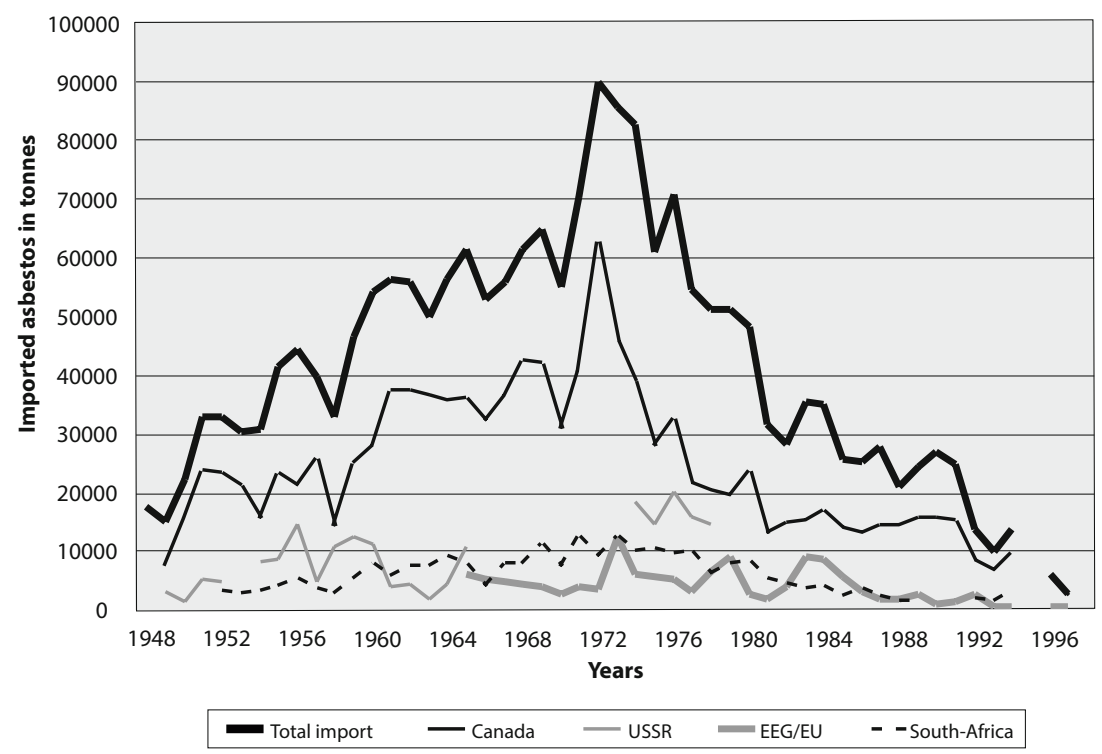

imported over the 50-year period, with 61 per cent of this purchased between 1960 and 1979. Import peaked in 1972 with 89,865 tonnes asbestos. By contrast, the Us Geological Survey reports a peak in 1975 which is almost 30,000 tonnes lower. ${ }^{21}$ Import figures decreased gradually from 1976 onward.

The annual statistics on foreign trade mention the 'most important' import countries. Information on the country of origin may help us deduce the type of asbestos. Two mineralogical groups can be discerned: serpentines and amphiboles. Studies indicate that amphibole types are even more hazardous than chrysotile asbestos, because of their physical and chemical characteristics. However, the degree of risk related to the type, shape and size of the fibres remains a matter of on-going debate. ${ }^{22}$ The serpentine group is characterised by curled fibres that split crossways. The only asbestos type within this group is chrysotile, used most commonly for industrial purposes. The amphiboles have straight, needle-like fibres that split lengthwise. Amphiboles crocidolite and amosite

21 Virta, Worldwide asbestos supply, 48.

22 R.F. Dodson, M.A.L. Atkinson and J.L. Levin, 'Asbestos fiber length as related to potential pathogenicity: A critical review', American Journal of Industrial Medicine 44 (2003) 291-297, DOI: $10.1002 /$ ajim.10263; D.W. Berman and K.S. Crump, 'Update of potency factors for asbestos-related lung cancer and mesothelioma', Critical Reviews in Toxicology 38 (2008) 1-47, DoI: 10.1080/10408440802276167. 
were commonly used in industrial applications. ${ }^{23}$ All types of asbestos minerals have been associated with adverse health effects. ${ }^{24}$

We find fifteen different countries of origin during the study period. Canada, South-Africa and the Soviet Union represent the three largest sources of import, accounting for respectively 55, 12 and 10 per cent of the total amount of imported raw asbestos. As Canada and the Soviet Union were major chrysotile exporters, we believe Belgium mainly purchased white asbestos. South-Africa uniquely produced five out of six types of asbestos but amosite and crocidolite dominated production in 1938-1982. ${ }^{25}$ Vande Weyer mentions the use of crocidolite from South-Africa in 1953-1972. ${ }^{26}$ South-Africa ended all amosite production and stopped exporting crocidolite to Belgium in $1992 .{ }^{27}$ Consequently, we infer that the large majority of Belgian asbestos manufacturing was based on chrysotile asbestos. Belgium probably also imported substantial amounts of the more dangerous amphibole asbestos.

Figure 2 shows that Belgium exported little raw asbestos from 1948 to 1998. Only 1 per cent of the imported two billion kg raw asbestos was sold abroad. It can be inferred that the vast majority of imported asbestos was probably stockpiled or used to manufacture products. Asbestos cement manufacturing dominated the industry almost from the start. A variety of other manufacturing processes relied on asbestos including the production of textile, automobile parts, electrical materials, paper and aluminium foil. ${ }^{28}$ Our analysis of trade statistics indicates that export of asbestos-containing products was relatively low during the 196os and 1970s. The quantity of exported asbestos products increased in the 1980s. Western European countries such as the Netherlands, France and the United Kingdom, were the prime outlets for Belgian asbestos products. With intensifying asbestos regulations in Europe, new markets opened up in Japan, Zaire (D.R. Congo) and Brazil among others.

23 R.L. Virta, Asbestos: Geology, mineralogy, mining and uses (Reston VA 2002) 2-9.

24 IARC, 'Asbestos (Chrysotile, amosite, crocidolite, tremolite, actinolite, and anthophyllite)', in: A review of human carcinogens. Part C: arsenic, metals, fibres, and fusts/IARC Working group on the evaluation of carcinogenic risks to humans 100 (Lyon 2012) 294.

25 Virta, Worldwide asbestos supply, 8-9.

26 R. Vande Weyer, 'Bilan de l'indemnisation de l'asbestose', Acta Tuberc Pneumol Belg 64 (1973) 308.

27 John S. Harington and Neil D. McGlashan, 'South African asbestos: Production, exports, and destinations, 1959-1993', American Journal of Industrial Medicine 33 (1998) 321, DOI: 10.1002/(SICI)1097o274(199804)33:4<321::AID-AJIM2>3.o.CO;2-X.

28 Van den Borre and Deboosere, 'The asbestos industry in Belgium (1945-2001)', 8-25. 
Figure 2 Import, export and consumption of raw asbestos in tonnes in Belgium and Luxembourg (1948-1998)

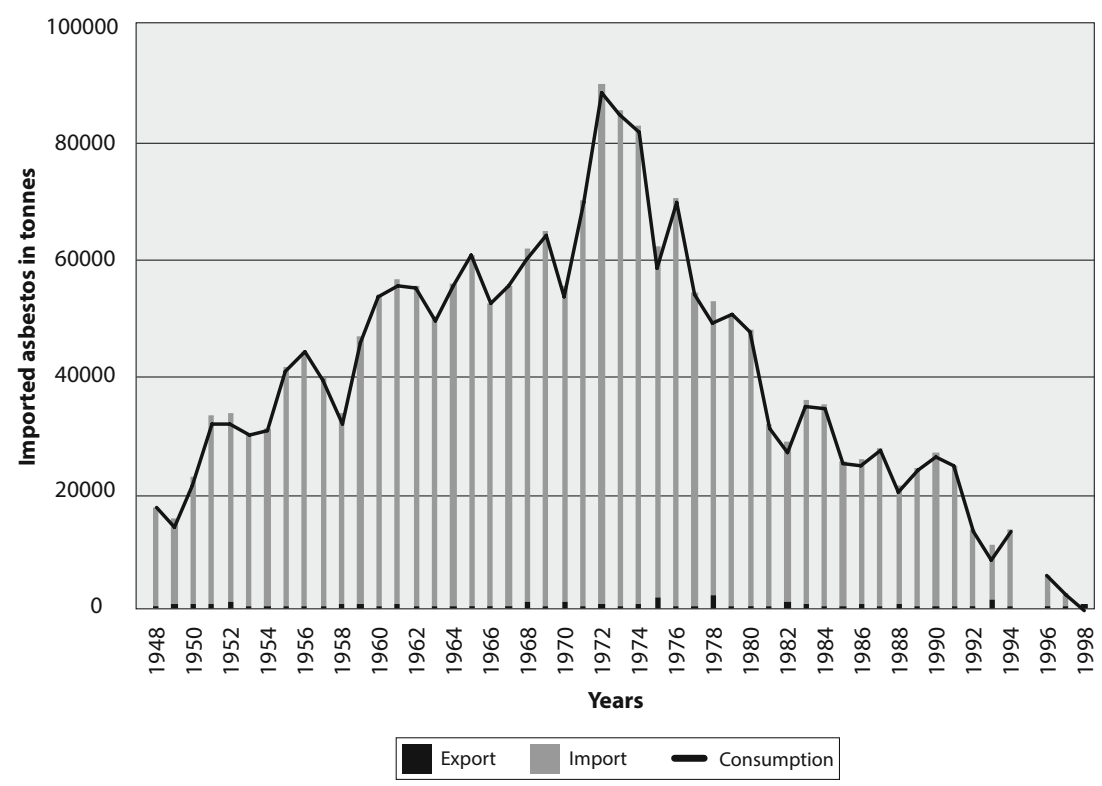

Figure 2 also demonstrates the gradual rise in asbestos consumption since 1948. Nawrot and colleagues have reported previously that Belgium had the highest asbestos consumption levels in the world in 1960-1969 with a mean annual consumption of $5.5 \mathrm{~kg}$ asbestos per capita. ${ }^{29}$ Our calculations for the same period indicate that the annual average was even higher with $6.0 \mathrm{~kg}$ asbestos per capita. After the fire in the shopping centre 'Innovation' in Brussels in 1967, the use of asbestos-containing materials was further promoted by the Belgian government. ${ }^{30}$ Per annum asbestos consumption peaked at 89,086 tonnes asbestos in 1972, after which a gradual decline began. That same year, Belgian legislators introduced dust reduction strategies in the general work safety regulations. ${ }^{31}$ Although some asbestos companies had already taken precautionary measures since the 1950s, the official plans for dust reduction in the work place constituted a first small step in the

29 Nawrot et al., 'Belgium: Historical champion in asbestos consumption', 1692.

$3^{\circ}$ E. de Kezel, Asbest, gezondheid en veiligheid. Ontwikkelingen in het aansprakelijkheidsrecht (Antwerpen 2013) 52, 123 .

31 Belgisch Staatsblad, 'Koninklijk Besluit van 23 Mei 1972 betreffende de strijd tegen de hinder door het werk en de werkplaatsen en tot wijziging van titel II, hoofdstuk III, van het algemeen reglement voor de Arbeidsbescherming', 1972. 
prevention of asbestos-related health risks. ${ }^{32}$ The first specific asbestos manufacturing regulations were passed in 1978. By then, consumption had already dropped 45 per cent since its peak. The law included a ban on the most dangerous applications including the use of crocidolite and friable asbestos with a transitioning period of two years. In addition, formal limits were set on the concentration of fibres in the air during manufacturing. ${ }^{33}$ In fact, most of the manufacturing companies had abandoned these techniques some years prior and had successfully implemented alternatives. The legislation was used mainly to stimulate stragglers to implement health protection measures during the production process. ${ }^{34}$

In the 1980s, European pressure on Belgium increased. A number of restrictions were implemented, driven primarily by European directives. However, these legislative efforts were characterised by many exemptions and long transition periods. The ten member countries of the European Economic Community (EEC) agreed in 1983 to limit the use and marketing of dangerous substances and chemicals, including asbestos. With some delay, Belgium implemented stricter asbestos regulations in the following years. Maximum occupational exposure levels were further limited in 1986, 1991 and $1993 .{ }^{35}$ Warning labels for asbestos-containing products became mandatory. ${ }^{36}$ Regulations for asbestos removal were stipulated.$^{37}$ The use of asbestos was prohibited in the manufacture of specific products, such as children's toys and cigarette filters. ${ }^{38}$ Every employer was obliged to make an inventory of asbestos-containing materials in the work place. ${ }^{39}$ However, enforcement was poor. Even after these legislative interventions, hazardous working

32 Salvatore Nay, Mortel Amiante (Brussels 1997) 36; Rechtbank van eerste aanleg te Brussel, Eindvonnis op tegenspraak in de zaakJonckheere-Vannoorbeeck vs. Eternit (2011) http://www.legalworld.be/legal world/content.aspx?id=4396o\&LangType=2067 (accessed 23 March 2017).

33 Belgisch Staatsblad, 'Koninklijk Besluit van 15 December 1978 tot wijziging van de titels II en III van het algemeen reglement voor de arbeidsbescherming, 1979.

34 De Kezel, Asbest, gezondheid en veiligheid, 136.

35 Belgisch Staatsblad, Koninklijk Besluit van 28 augustus 1986 betreffende de strijd tegen de risico's te wijten aan asbest, 1986; Belgisch Staatsblad, Koninklijk Besluit van 22 juli 1991 tot wijziging en aanvulling, wat de bescherming tegen asbest betreft, van het algemeen reglement voor de arbeidsbescherming, 1991; Belgisch Staatsblad, Koninklijk Besluit van 2 december 1993 betreffende de bescherming van de werknemers tegen de risico's van blootstelling aan carcinogene agentia op het werk, 1993.

36 Belgisch Staatsblad, Koninklijk Besluit van 28 augustus 1986.

37 Ibidem

38 Belgisch Staatsblad, Koninklijk Besluit van 29 december 1988 inzake voorkoming en vermindering van verontreiniging van de lucht door asbest, 1988.

39 Belgisch Staatsblad, Koninklijk Besluit van 22 Juli 1991. 
conditions were reported. ${ }^{40}$ The implementation of asbestos inventories failed. As a result, it is not possible to estimate how much asbestos is still in place. ${ }^{41}$

Some fifteen years after the first asbestos ban in Iceland, Belgium banned the use and marketing of asbestos in $1998 .^{42}$ Exceptions were made for some chrysotile products until a second ban in 2001. ${ }^{43}$ Manufacturing of one industrial chrysotile application continued until the European ban in 2005 .

\section{Association between asbestos consumption and meso- thelioma mortality}

The respiratory health risks of asbestos exposure were reported as early as 1898 , when one of the first Lady Inspectors of Factories investigated the working conditions of British textile workers. ${ }^{44}$ After several reports of pulmonary fibrosis among asbestos workers, the term 'asbestosis' was introduced in $1924 .{ }^{45}$ The first accounts of possible carcinogenic effects of asbestos date from 1930-1940. In 1955, Doll published his famous study on lung cancer mortality among asbestos workers in Rochdale. ${ }^{46}$ A few years later, South African researchers Wagner, Sleggs and Marchand found an association between asbestos exposure and a rare type of cancer at the time: pleural mesothelioma. ${ }^{47}$ The study demonstrated not only the risks due to occupational exposure but also those due to environmental and second hand exposure. Although first reports of asbestos-induced laryngeal and ovarian cancer were published in circa

40 Nay,MortelAmiante;MichelVerniers,LavieálaS.A.Fabrecim Coveritracontée par MichelVerniers, n.d., http://www.abeva.eu/index.php/nl/abeva/13-categories-fr/communiques/58-la-vie-a-la-s-a-fabrecimcoverit-racontee-par-michel-verniers (accessed 16 March 2017).

41 Ecorem, Inventarisatiestudie Asbesthoudende Materiaalstromen in Vlaanderen (Mechelen 2013). 42 Belgisch Staatsblad, Koninklijk Besluit van 3 februari 1998 tot beperking van het op de markt brengen, de vervaardiging en het gebruik van bepaalde gevaarlijke stoffen en preparaten (asbest), 1998.

43 Belgisch Staatsblad, Koninklijk Besluit van 23 oktober 2001 tot beperking van het op de markt brengen, de vervaardiging en het gebruik van bepaalde gevaarlijke stoffen en preparaten (asbest), 2001.

44 UK Factory Inspectorate, 'Annual report chief inspector factories and workshops for the year 1898' (London 1898).

45 W.E. Cooke, 'Fibrosis of the lungs due to the inhalation of asbestos dust', British Medical Journal II (1924) 147-148.

46 R. Doll, 'Mortality from lung cancer in asbestos workers', British Journal of Industrial Medicine 12 (1955) 81-86.

47 J.C. Wagner, C.A. Sleggs and P. Marchand, 'Diffuse pleural mesothelioma and asbestos exposure in the North Western Cape province', British Journal of Industrial Medicine 17 (1960) 260-271. 
$1970,{ }^{48}$ these malignancies were only recently acknowledged as asbestos-related diseases by the International Agency for Research on Cancer (IARC) ${ }^{49}$

Despite strong international evidence, the health effects of asbestos remained scarcely researched in Belgium. Epidemiological data were not available for a long time. Contrary to other European countries, no ad hoc registries for asbestos-related diseases were established..$^{50}$ The first studies were based on company or indemnification records of questionable accuracy. ${ }^{51}$ Mortality among workers and inhabitants of the factory area was examined in 1967 at the request of asbestos cement manufacturer Eternit. No significant differences were observed for asbestos-related diseases. ${ }^{52}$ The pathological aspects of asbestosis and associated causes of death were described in 1973 and 1981 using data from the Occupational Diseases Fund. ${ }^{53}$ Lacquet, van der Linden and Eternit company doctor Lepoutre examined health records of asbestos cement workers in $1980 .{ }^{54}$ Results show respiratory cancer mortality was similar to the general population and asbestosis cases were strongly related to high levels of exposure. From the late 1980s onward, a number of biomedical studies were performed. ${ }^{55}$ The impact of as-

48 J. Graham and R. Graham, 'Ovarian cancer and asbestos', Environmental Research 1 (1967) 115-128; P.M. Stell and T. Mcgill, 'Asbestos and laryngeal carcinoma', The Lancet 2 (1973) 416-417, DoI: 10.1016/ So140-6736(73)92275-7.

49 Kurt Straif et al., 'A review of human carcinogens - Part C: Metals, arsenic, dusts, and fibres', The Lancet Oncology 10 (2009) 453-454, DOI: 10.1016/S1470-2045(o9)70134-2.

$5^{\circ}$ Andrea Boggio, Compensating asbestos victims: Law and the dark side of industrialization (New York 2016) 1-279.

51 Marc Molitor, Négociations et tensions autour de la création du fonds amiante, Courrier h (Brussels 2010), http://www.avae-vvba.be/modules/inventaire_details.php?id=5\&lang=fr; Nay, Mortel Amiante; J. Thimpont et al., 'Les missions du fonds des maladies professionelles. Le sous-déclaration des cancers respiratoires professionnels, en particulier dus à l'amiante [The missions of the occupational diseases fund. Under-claim and recognition of occupational lung cancer, in particular those related to asbestos]', Revue Medicale De Bruxelles 30 (2009) 318-325.

$5^{2}$ H. Van De Voorde et al., 'Doodsoorzaken bij de bevolking woonachtig rond en bij de arbeiders werkzaam in een asbestverwerkende nijverheid in het noorden van Brabant', Acta Tuberc Pneumol Belg 58 (1967) 924-942.

53 The occupational diseases fund merged with the occupational accidents fund on 1 January 2017. The funds have been renamed as Fedris (Federal agency for occupational risks); R. Vande Weyer, 'Pathologie Respiratoire de L’amiante En Belgique', Rev Méd Brux 2 (1981) 69-81.

54 L.M. Lacquet, L. van der Linden and J. Lepoutre, 'Roentgenographic lung changes, asbestosis and mortality in a Belgian asbestos-cement factory', in: J.C. Wagner (ed.), Biological effects of mineral fibres. IARC Scientific Publication 30 (Lyon 1980) 783-795.

55 P. De Vuyst, P. Dumortier and P.A. Gevenois, 'Analysis of asbestos bodies in BAL from subjects with particular exposures', American Journal of Industrial Medicine 31 (1997) 699-704; P. De Vuyst et al., 'Asbestos bodies in bronchoalveolar lavage reflect lung asbestos body concentration', The European Respiratory Jour- 


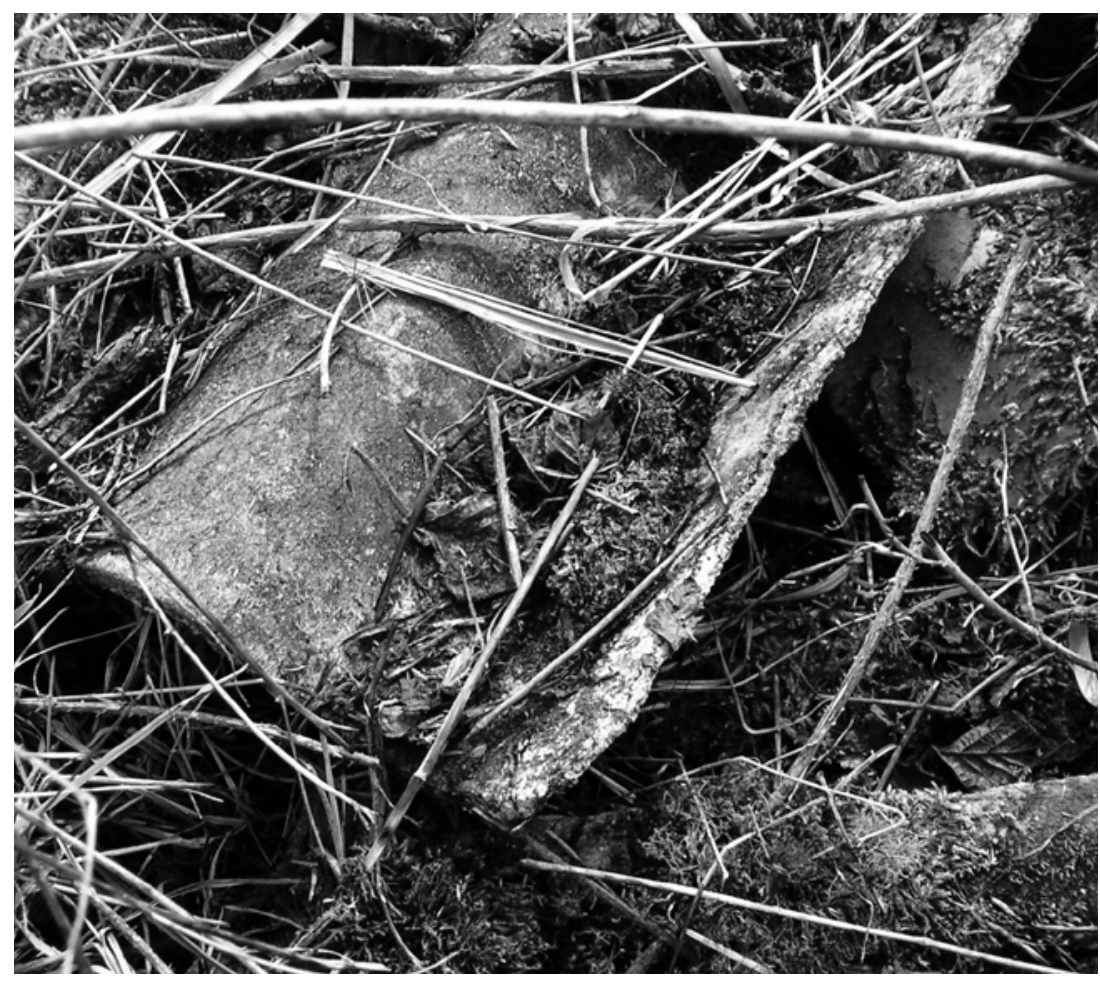

Illustration 1 The unsafe disposal of asbestos-containing material poses current-day risks of environmental exposure (source: Library Morguefile).

bestos on population health was only recently analyzed using national death certificate data and cancer registry data. ${ }^{56}$

Previous research by the authors focused on time trends in mesothelioma mortality in Belgium. ${ }^{57}$ Malignant mesothelioma is a potent and sensitive indicator for asbestos-related mortality as almost all cases are caused by asbestos exposure. Mesothelioma can be induced by low

nal 1 (1988) 362-367; P. Dumortier et al., 'Trends in asbestos body counts in bronchoalveolar lavage fluid over two decades', The European Respiratory Journal 22 (2003) 519-524; Kevin Hollevoet et al., 'Serial measurements of mesothelioma serum biomarkers in asbestos-exposed individuals: A prospective longitudinal cohort study', Journal of Thoracic Oncology 6 (2011) 889-895, DOI: 10.1097/JTO.obo13e3182odb377. 56 Laura Van den Borre and Patrick Deboosere, 'Enduring health effects of asbestos use in Belgian industries: A record-linked cohort study of cause-specific mortality (2001-2009)', BMJ Open 5 (2015) 1-10, DOI: 10.1136/bmjopen-2014-007384; Van den Borre and Deboosere, 'Asbestos in Belgium: An underestimated health risk'; Thomas Neyens et al., 'Disease mapping of zero-excessive mesothelioma data in Flanders', Annals of Epidemiology (2016) 59-66, DoI: 10.1016/j.annepidem.2016.10.0o6. 57 Van den Borre and Deboosere, 'Asbestos in Belgium: An underestimated health risk'. 
levels of exposure. ${ }^{58}$ This tumour develops in the protective linings that cover the lungs, chest wall, abdomen and heart. Average latency periods have been reported ranging from 17-45 years. ${ }^{59}$ Despite some modest improvements in treatment, mesothelioma has very poor survival rates. ${ }^{60}$

The present study provides an update with newly available data for mesothelioma mortality in 2000-2003 and in 2010-2014. Mesothelioma deaths were derived from the World Health Organization Mortality Database (1969-1986) and the Belgian Scientific Institute of Public Health (1987-2014).$^{61}$ Mortality data from the wHO database show there were almost no recorded Belgian mesothelioma deaths prior to 1969 . Linear interpolation is used to replace the missing values in 1985. Mesothelioma is defined using the International Classification of Diseases (ICD) coding system. Only revision 10 includes specific codes for mesothelioma (ICD-10 C45). Prior to 1998, pleural cancer was used as an indirect indicator of mesothelioma. For the periods 19691978 and 1979-1997, we respectively used ICD-8 163.0 and ICD-9 163 . Directly standardized mortality rates (AAMRs) were calculated using the 2013 European standard population as reference. Time trends for asbestos consumption levels and mesothelioma rates were modelled as fourth degree polynomials.

Figure 3 presents trends in asbestos consumption with mesothelioma mortality rates by sex. Male mesothelioma rates follow a similar trend to asbestos consumption levels per capita. In 1948, Belgium consumed two kg raw asbestos per capita. At the peak of the consumption in 1972, the country used almost ten $\mathrm{kg}$ raw asbestos per Belgian. Consumption levels dropped below two kg per capita only in the early 1990s. At the time of the first formal asbestos ban, consumption per capita dropped to -0.07 kg indicating an export from stock in 1998.

58 G. Hillerdal, 'Mesothelioma: Cases associated with non-occupational and low dose exposures', Occupational and Environmental Medicine 56 (1999) 505-513, DoI: 10.1136/oem.56.8.505.

59 Alessandro Marinaccio et al., 'Analysis of latency time and its determinants in asbestos related malignant mesothelioma cases of the Italian register', European Journal of Cancer 43 (2007) 2725, DoI: 10.1016/j.ejca.2007.09.018; G. Frost, 'The latency period of mesothelioma among a cohort of British asbestos workers (1978-2005)', British Journal of Cancer 109 (2013) 1971, DOI: 10.1038/bjc.2013.514. 6o Jennifer L. Beebe-Dimmer et al., 'Mesothelioma in the United States: A surveillance, epidemiology, and end results (SEER)-Medicare investigation of treatment patterns and overall survival', Clinical Epidemiology 8 (2016) 745-748, DOI: 10.2147/CLEP.S105396.

61 World Health Organization (wHO) global health observatory, wHO mortality database: World health organization statistical information system (WHOSIS).; Scientific Institute of Public Health, 'Standardized procedures for mortality analysis', n.d., https://www.wiv-isp.be/epidemio/spma (accessed 15 May 2017). 
Figure 3 Asbestos consumption in kg per capita with age-adjusted mortality rates for mesothelioma by sex (1948-2014)

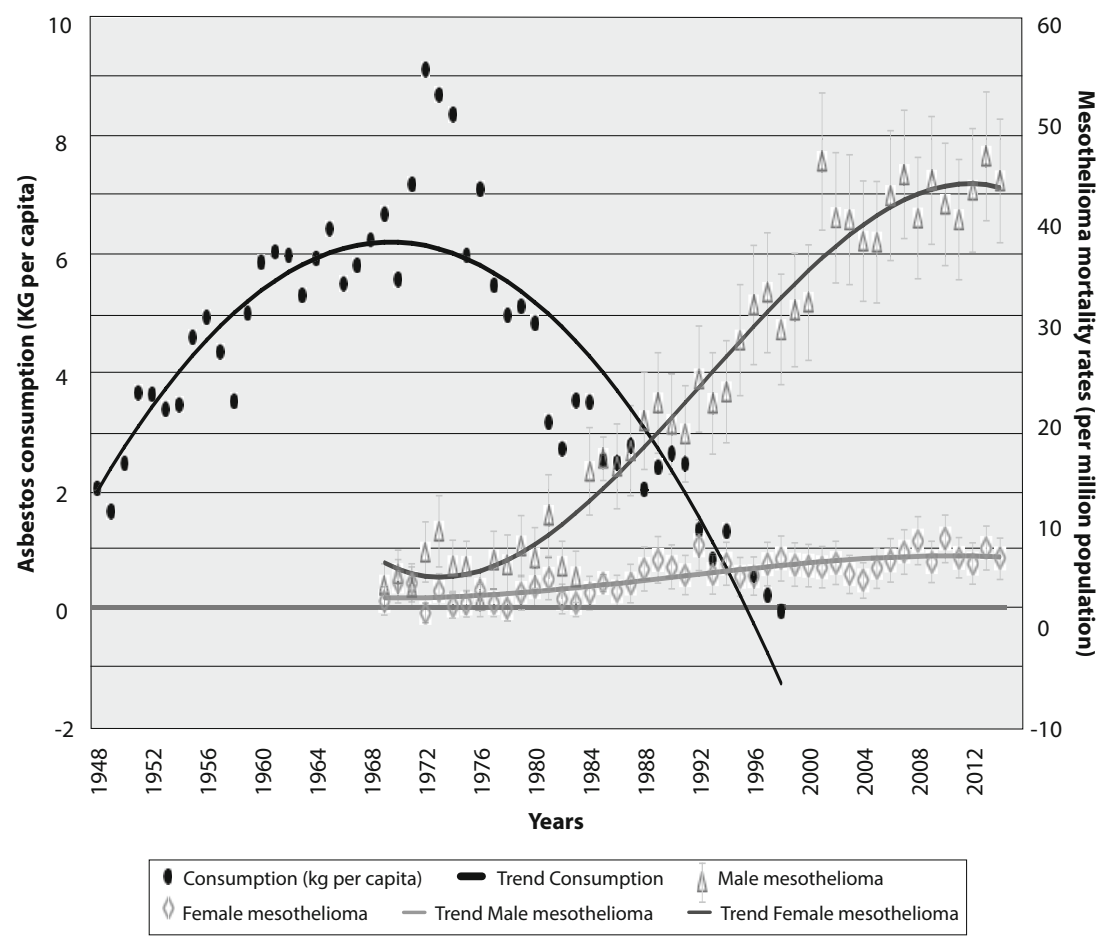

Asbestos consumption levels peaked in 1960-1975, while the trend indicates a peak in male mesothelioma mortality in 2001-2018. The time lag of approximately 40 years corresponds to the average latency period for malignant mesothelioma. ${ }^{62}$ Male mesothelioma rates increased more than tenfold from 3.8 to 44.1 deaths per million between 1969 and 2014. Mesothelioma mortality among women tripled over the 45-year period from 2.3 to 6.5 deaths per million population. A sharp divergence between the sexes appeared, with the rising mortality rates for men in the mid-198os. The male-to-female ratio tripled from 2.3 in 1983 to 6.5 in 2014. Changes in the recording of causes of death are an unlikely explanation for this strong increase. The revisions of the ICD-codes in 1979 and 1998 do not appear to influence recorded mesothelioma mortality. In addition, any differences in registration should also affect female mesothelioma deaths, which increased more moderately. The 
sharp increase in male deaths in the mid-1980s is probably the result of the expansion of the asbestos industry and augmented occupational exposure some 40 years prior. Only a small proportion of women worked in asbestos industries. ${ }^{63}$ As a result, the gradual rise in female mortality is more likely affected by increased secondary (e.g. indirect contact via family members) and environmental (e.g. air pollution) exposure. ${ }^{64}$

\section{Reasons for slow government action}

The question arises: why was the Belgian government so late to intervene in the recognition of the asbestos problem and the regulation of its usage? Table 1 presents a time-line of key events related to asbestos with a focus on Belgium.

A literature review was performed to clarify the underlying reasons. Academic literature from health, law, economics, politics and civil engineering were retrieved using the Union Catalogue of Belgian Libraries, the MEDLINE-database and the online databases from the Vrije Universiteit Brussel (VUB). Various government documents were scrutinized, including committee hearings and trade statistics. Legislative documents were examined such as proposals for new bills and the ruling of the Belgian Eternit trial. Indemnification information was retrieved from the Occupational Diseases Fund and the Asbestos Fund. The website from the Belgian Association for Asbestos Victims (ABEVA) was consulted to retrieve specific information on asbestos victims. Finally, local, national and international media were consulted using the GoPress database and the archives of broadcasting networks.

\section{Long latency periods}

Belgium was among the first countries to manufacture asbestos products on a large scale. ${ }^{65}$ For a long time, the risk of adverse health effects associated with asbestos exposure was not perceived as problematic. As-

63 Van den Borre and Deboosere, 'Enduring health effects of asbestos use in Belgian industries: A record-linked cohort study of cause-specific mortality (2001-2009)', 4.

64 N.J. Vianna and A.K. Polan, 'Non-occupational exposure to asbestos and malignant mesothelioma in females', Lancet 52 (1978) 1061-1063; J.C. McDonald, 'Health implications of environmental exposure to asbestos', Environmental Health Perspectives 62 (1985) 319-328; M.T. Madkour et al., 'Environmental exposure to asbestos and the exposure-response relationship with mesothelioma', Eastern Mediterranean Health Journal 15 (2009) 25-38.

65 Virta, Worldwide Asbestos Supply, 13. 
Table 1 Key events related to asbestos use in Belgium

\begin{tabular}{|l|l|l|}
\hline Year & & \multicolumn{1}{|c|}{ Event } \\
\hline 1905 & Asbestos cement manufacturer Eternit Belgium is founded \\
\hline 1924 & First mention of term 'Asbestosis' \\
\hline 1953 & Belgium acknowledges asbestosis as an occupational disease \\
\hline 1955 & Doll reports association between asbestos exposure and lung cancer \\
\hline 1960 & Wagner et al. report association between asbestos exposure and malignant mesothelioma \\
\hline 1978 & Belgium bans most dangerous applications: crocidolite and friable asbestos \\
\hline 1982 & Belgium acknowledges malignant mesothelioma as an occupational disease \\
\hline 1983 & Iceland is the first country to ban all asbestos types (with exemptions) \\
\hline 1993 & The Netherlands ban all asbestos types \\
\hline 1998 & Belgium bans all types of amphibole asbestos and some chrysotile products \\
\hline 1999 & Belgium acknowledges asbestos-induced lung cancer as an occupational disease \\
\hline 2000 & Belgian Asbestos Victims Association is founded \\
\hline 2001 & Belgian ban on all types of asbestos (with some exemptions) \\
\hline 2002 & Belgium acknowledges asbestos-induced laryngeal cancer as an occupational disease (with restrictions) \\
\hline 2005 & The European Union bans all types of asbestos \\
\hline 2007 & Asbestos Fund reimburses (non-)occupational asbestosis and mesothelioma. \\
\hline 2018 & Canada bans all asbestos types \\
\hline & \\
\hline
\end{tabular}

bestos-related diseases typically have long latency periods. The period between asbestos exposure and the onset of the symptoms can take up to several decades. ${ }^{66}$ As a result, asbestos-related health effects only appeared when the asbestos industry was a well-established part of the Belgian economy. The general public was mostly unaware of the implications of the international evidence. The notion of developing asbestos-related diseases was perhaps too far removed from their personal lives at the time.

\section{Strong asbestos lobby}

A powerful asbestos lobby was present in Belgium. Misinformation and political pressure were used to prolong the use of asbestos. The Emsens family, owner of one of the largest European asbestos groups Eternit, had strong ties with the Belgian aristocracy, financial executives and 
industrial leaders. ${ }^{67}$ Economic partnerships between Eternit Belgium and the other international branches were consolidated when several Emsens family members married into the French and Swiss Eternit families. ${ }^{68}$ Asbestos companies from around the globe entered into commercial alliances in response to the scientific findings during the 196 os. $^{69}$ This cartelisation resulted in the creation of international lobby groups such as the Asbestos International Association (AIA) in 1970. That same year, Belgian and Dutch asbestos companies united as the Comité d'Information de l'Amiante-Benelux (CIA-B). As a part of the AIA, the CIA-B has the same objective: gathering and spreading information on asbestos, asbestos-containing products and the use of these materials. ${ }^{70}$ The discourse bears strong resemblances with the tobacco industry where the strategy of manufacturing uncertainty originated. ${ }^{71}$ The validity of sound scientific evidence was questioned by producers or hired experts to postpone or annul industry regulations. One of the key strategies of the AIA involved minimizing health risks of - the highly profitable-chrysotile asbestos. An important argument refers to the Stanton hypothesis. Stanton and colleagues consider the possibility that chrysotile fibres are cleared more easily after inhalation than amphibole fibres due to different fibre morphology. ${ }^{72}$ Canadian studies supporting the hypothesis were openly or covertly sponsored by chrysotile mining companies. ${ }^{73}$ Although clearance may differ according to the fibre size, recent research shows shorter chrysotile fibres may also

67 Alain Finet and Romina Giuliano, 'Le groupe cimentier Eternit et le scandale de l'amiante: Essai d'explication par la gouvernance', La Revue Des Sciences de Gestion 5 (2012) 33-42, DoI: 10.3917/ rsg.257.0033.

68 Ibidem.

69 Jock McCulloch and Geoffrey Tweedale, Defending the indefensible: The global asbestos industry and its fight for survival (New York 2008) 59.

70 De Kezel, Asbest, gezondheid en veiligheid, 636-640.

71 David Michaels and Celeste Monforton, 'Manufacturing uncertainty: Contested science and the protection of the public's health and environment', American Journal of Public Health 95 (2005) S39-48, DOI: 10.2105/AJPH.2004.043059.

72 M.F. Stanton et al., 'Relation of particle dimension to carcinogenicity in amphibole asbestoses and other fibrous minerals', Journal of the National Cancer Institute 67 (1981) 965-975.

73 F.D. Liddell, A.D. McDonald and J.C. McDonald, 'The 1891-1920 birth cohort of Quebec chrysotile miners and millers: Development from 1904 and mortality to 1992', The Annals of Occupational Hygiene 41 (1997) 13-36, DOI: 10.1016/Sooo3-4878(96)ooo44-о; СвС News, 'McGill asbestos study flawed, epidemiologist says (News article published online 2 February 2012)', cBC News 2012, http:// www.cbc.ca/news/canada/mcgill-asbestos-study-flawed-epidemiologist-says-1.1249464 (accessed 28 April 2017); D.M. Bernstein, 'The health risk of chrysotile asbestos', Current Opinion in Pulmonary Medicine 20 (2014) 366-370, DOI: 10.1097/MCP.oooooooooooooo64. 


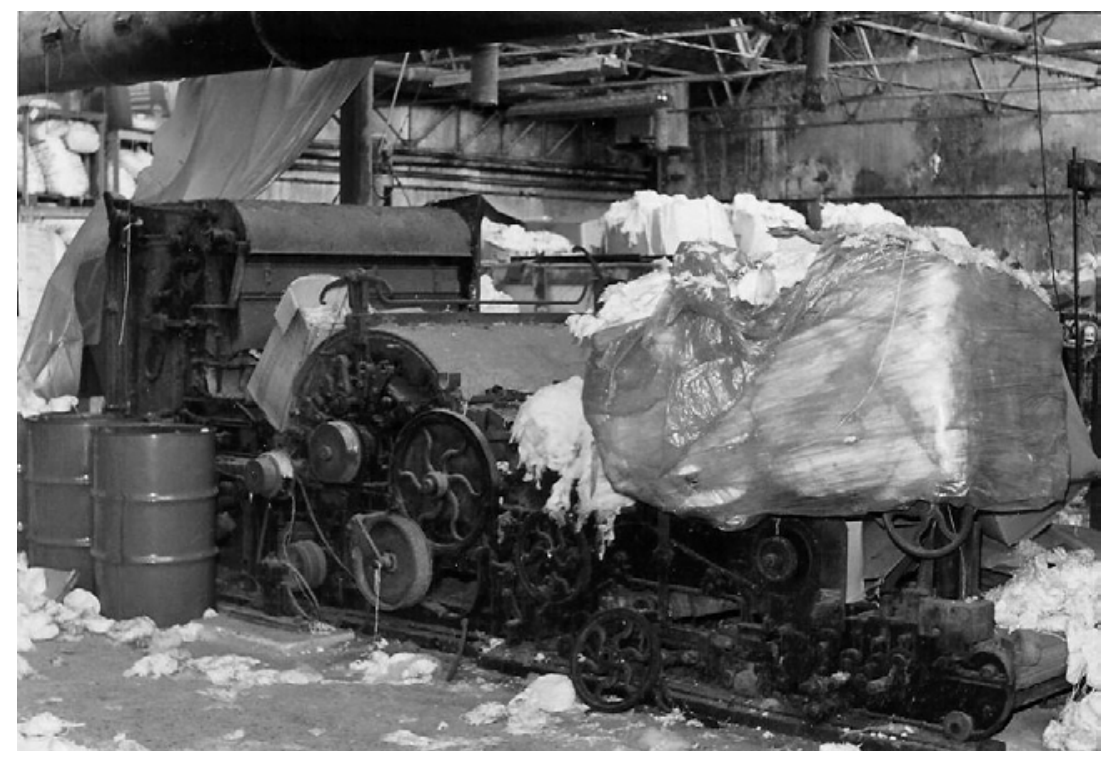

Illustration 2 Weaving loom covered with asbestos fibres in the factory of La Manufacture de l'Amiante et de Caoutchouc in Deurne, Belgium (source: Archive Turninum Volksmuseum Deurne).

cause mesothelioma.$^{74}$ All asbestos types have been classified as class I carcinogens by the IARC. ${ }^{75}$

The asbestos industry was a strong actor in the national and international decision-making process. ${ }^{76}$ The AIA shared technical knowledge, promoted asbestos use and provided political strategies. Through its membership in the Union of European Community Industries, asbestos manufacturers were able to maintain good relations with European policy makers. ${ }^{77}$ Belgium played a pivotal role in the international asbestos lobby when Etienne Van der Rest, grandson of Eternit Belgium founder Alphonse Emsens, became president of the AIA in the $1980{ }^{78}$

De Kezel investigated national asbestos legislation and found exceptionally slow government intervention in Belgium compared to the Netherlands and France. ${ }^{79}$ With the CIA-B, Belgian asbestos manufactur-

74 Yasunosuke Suzuki, Steven Yuen and Richard Ashley, 'Short, thin asbestos fibers contribute to the development of human malignant mesothelioma: Pathological evidence', International Journal of Hygiene and Environmental Health 208 (2005) 201-210, DOI: 10.1016/j.jjheh.2005.01.015.

75 Straif et al., 'A review of human carcinogens_Part C: Metals, arsenic, dusts, and fibres'.

76 Anne Bergmans and Ilse Loots, 'Asbest in gebouwen: Ook voor bestuurders niet zo goed', 1998, 1920.

77 Robert Frank Ruers, 'Macht en tegenmacht in de Nederlandse asbestregulering', 265.

78 McCulloch and Tweedale, Defending the indefensible, 117.

79 De Kezel, Asbest, gezondheid en veiligheid, 135-187. 
ers acted as a strong industrial block. The economic importance of asbestos products in key industries was a powerful argument against the reduction of asbestos use. Legislative measures were impeded due to conflicting objectives such as public health concerns and financial interests. As a result, much of the initiative in regulating the industry was left to asbestos manufacturers. ${ }^{80}$

\section{Slowly emerging opposition}

Asbestos victims were not represented in the decision-making process. The Belgian Asbestos Victims Association (ABEVA) was only founded in $2000 .{ }^{81}$ The slow process of organizing victims was influenced by a number of factors. Many asbestos manufacturers had gone bankrupt, leaving no-one to be held responsible. ${ }^{82}$ The remaining companies exerted pressure on former employees to conceal the extent of the problem. ABEVA president Eric Jonckheere reports that asbestos victims received a financial donation from manufacturers in return for their silence..$^{83}$ In addition, asbestos manufacturers held more than financial influence. Many workers were dedicated to their employers. Companies often fulfilled an important societal role in the factory area. Asbestos cement manufacturer Eternit, for example, had its own sports centre for employees and inhabitants of the area. Many workers could not believe that their employers wilfully endangered the work force.$^{84}$ If asbestos victims were inclined to go to trial, they were discouraged by the tedious and difficult juridical process. ${ }^{85}$ Dutch political scientist Ruers highlights the importance of civil procedures in the regulation of the power balance between asbestos victims and manufacturers. ${ }^{86}$ Not one manufacturer was trialled for exposing workers to asbestos in Belgium. The Italian Eternit trial stands in marked contrast as workers and inhabitants of the factory area worked together to hold the Italian asbestos cement branch accountable. ${ }^{87}$

8o Bergmans and Loots, 'Asbest in gebouwen', 24.

81 ABEVA, 'Présentation de l'association', ABEva Website, http://home.scarlet.be/ abeva/f_update.htm (accessed 4 May 2017).

82 De Kezel, Asbest, gezondheid en veiligheid, 228-280.

83 Eric Jonckheere, Ma guerre contre l'amiante, témoignage \& document (Lons-le-Saunier 2013) 131139 .

84 De Kezel, Asbest, gezondheid en veiligheid, 626-629.

85 Ibidem.

86 Ruers, 'Macht en tegenmacht in de Nederlandse asbestregulering', 492.

87 International Ban Asbestos Secretariat 'Eternit and the great asbestos trial'(London 2012) 1-94, 43. 
Worker unions followed the industry's rationale for a long time out of concern for unemployment. According to de Kezel, Belgian trade unions acted late in comparison with other important asbestos-manufacturing countries such as the Netherlands, Italy and the United Kingdom. The delayed initiative from Belgian worker unions can be explained by the strong influence of asbestos manufacturers. ${ }^{88}$ Union support for stricter regulation also increased since the $198 \mathrm{os}^{89}{ }^{89}$ Although imperative in the awareness process of asbestos-related risks, union efforts remained largely unsuccessful in changing policy in the face of such a powerful asbestos lobby. ${ }^{90}$

\section{Media coverage}

From the late 1970s onwards, asbestos-related health hazards gradually gained media attention in Belgium. The public broadcasting company of the French speaking community (RTBF) featured a TV-episode on the working conditions and health risks in a Belgian asbestos cement factory in $1977 \cdot{ }^{91}$ In 1984, both the French-speaking and Dutch-speaking public television networks aired extracts of the British documentary 'Alice, a fight for life' about an asbestos worker battling mesothelioma. ${ }^{92}$ In 1987, a television broadcast on occupational health risks mentioned that: 'by now, everybody knows that asbestos is not exactly beneficial for one's health. ${ }^{93}$ Still, the broadcasts did not have much impact on the general public and the political process. Media attention for asbestos remained relatively low until the 199os. The vacating of the European Commission's headquarters in 1991 is considered to be one of the turning points. ${ }^{94}$ The contamination of the Berlaymont building with asbes-

88 De Kezel, Asbest, gezondheid en veiligheid, 621-626.

89 Belgische Kamer van Volksvertegenwoordigers, 'Wetsvoorstel betreffende de bescherming van mens en milieu tegen de schadelijke gevolgen van asbest', Pub. L. No. 357/5-1988, uitgebracht door de heer Leroy (1989), http://www.dekamer.be/digidoc/DPS/K2045/K20451880/K2045188o.pdf (accessed 14 August 2017).

90 Andrea Boggio, Compensating asbestos victims: Law and the dark side of industrialization (New York 2016), $38-43$.

91 M.-A. Mengeot and S. Nay, 'Work and health: To die for asbestos-le travail où la santé: Mourir de l'amiante' (RTBF television production, 1977), http://euscreen.eu/item.html?id=EUS_79589CB4748 F425B8F818B2125B8BD93.

92 Nay, Mortel Amiante; J. Willis, 'A suivre: Alice, a fight for life' (RTBF television production 28 September 1984; VRT television production (24 May 1984).

93 D. Everaert, 'Giftige sluipmoordenaars op het werk', Loon Naar Werken (VRT television production, 5 January 1987).

94 S. Nay, 'Asbestos in Belgium: Use and abuse', International Journal of Occupational and Environmental Health 9 (2003) 292, DOI: 10.1179/oeh.2003.9.3.287. 
tos demonstrated that the problem extended beyond the factory floor. ${ }^{95}$ Social scientists Bergmans and Loots note that news coverage mainly focused on specific local asbestos issues. News items on specific exposure cases helped concretize the asbestos problem, but it scarcely led to a broad public awareness of asbestos-related health risks in Belgium. ${ }^{96}$ The first and only asbestos trial in Belgium fuelled the public debate in recent years. In 2017 , Eternit was found guilty of causing the death of an environmental mesothelioma victim after a juridical battle of seventeen years. ${ }^{97}$ In the wake of the trial, even popular tabloids covered the topic, with television personalities Thomas Vanderveken and Tina Maerevoet sharing their personal experiences with asbestos. ${ }^{98}$

\section{Conclusion}

Asbestos became a part of the social, political, economic and environmental fabric of Belgian society. A staggering two billion tonnes of raw asbestos were imported between 1948 and 1998. The asbestos-cement industry dominated asbestos manufacturing, but many other industries depended on the use of the so-called magic mineral. Knowledge about asbestos-related health risks spread beyond the scientific community from the late 196os. However, risk awareness was hampered by the long latency periods of the diseases and false reassurances from the asbestos lobby. Even after policy makers and the general public acknowledged the problem, the Belgian government failed to manage and prevent further asbestos exposure in a timely fashion. Future public health was sacrificed in favour of industrial development, economic advancement and political gain.

The long history of industrial asbestos use is unfolding with severe consequences on population health. Belgian mesothelioma mortality is fourth highest in the world. ${ }^{99}$ Our results show that mesothelioma deaths are currently reaching new heights. Male mesothelioma deaths are expected to peak in 2001-2018 which corresponds with the expansion of the asbestos industry 40 years earlier. The gradual increase of

95 Molitor, Négociations et tensions autour de la création du fonds amiante, 28-29.

96 Bergmans and Loots, 'Asbest in Gebouwen', 24-25.

97 Het Nieuwsblad, 'Eternit mag familie asbestslachtoffer lagere schadevergoeding betalen in beroep (Published on 28 March 2017)', http://www.nieuwsblad.be/cnt/dmf20170328_o2803859. 98 TV-Familie, 'Pure Maffia!' (5 April 2017), 21; Story, 'Asbest zit nog altijd overal' (4 April 2017), 12. 99 Van den Borre and Deboosere, 'Asbestos in Belgium: An underestimated health risk', 126. 
female mesothelioma deaths can be explained by the lower number of women occupationally exposed.

Although mesothelioma is a strong indicator of asbestos exposure, this disease adds only in part to the understanding of the overall asbestos problem. Establishing the total impact of asbestos on population health is difficult due to the existence of co-carcinogens for lung cancer, laryngeal cancer and ovarian cancer. ${ }^{100}$ It is highly likely that mesothelioma deaths represent only the tip of the iceberg.

Belgium is still dealing with the aftermath of decades of asbestos use. Compensation for asbestos victims has improved. Since 2007, non-occupational asbestos victims can be compensated by the Asbestos Fund. Unfortunately, the fund only provides compensations for mesothelioma and asbestosis. ${ }^{101}$ Belgian law makes it almost impossible to hold asbestos manufacturers accountable. If victims receive reimbursements from the Asbestos Fund or the Occupational Diseases Fund, they cannot claim damages in tort cases. ${ }^{102}$ Personal injury litigation such as in the Netherlands, Italy and the UK is not possible in Belgium, unless victims can prove they were intentionally exposed to asbestos. ${ }^{103}$ During the recent asbestos trial in Belgium, victims were able to express their outrage for the first time in court. ${ }^{104}$ In our opinion, modifications to the tort immunity is imperative in the pursuit of personal and national reconciliation with the asbestos past.

The most recent development is the plan for an Asbestos Safe Flanders to prevent current-day asbestos exposure. The Flemish government aims to remove asbestos-containing materials from society by 2040 . The Flemish waste management service is currently performing preliminary examinations and test projects. ${ }^{105}$ The green political party Groen has already proposed to accelerate the project. ${ }^{106}$ To our knowledge, no similar plans are being drawn up in the Walloon Region and the Brus-

\footnotetext{
100 IARC, 'Asbestos (Chrysotile, amosite, crocidolite, tremolite, actinolite, and anthophyllite)'.

101 Asbestfonds/Fonds amiante, 'Criteria voor erkenning en vergoeding van asbestziekten door het Asbestfonds', n.d., 1-42.

102 De Kezel, Asbest, gezondheid en veiligheid, 527-537.

103 Boggio, Compensating asbestos victims, 38-43; De Kezel, Asbest, gezondheid en veilighei, 527-237.

104 Rechtbank van eerste aanleg te Brussel, Eindvonnis op tegenspraak in de zaakJonckheere-Vannoorbeeck vs. Eternit.

105 OvAM, 'Asbestveilig Vlaanderen 2040 doorstartfase 2015-2018', 2017, https://www.ovam.be/asbestveilig-vlaanderen-2040-doorstartfase-2015-2018 (accessed 28 April 2017).

106 Johan Danen and Björn Rzoska, 'Voorstel van resolutie betreffende de versnelling van asbestsaneringsbeleid in Vlaanderen' (Vlaams Parlement, 2016), https://docs.vlaamsparlement.be/docs/stukken/2016-2017/g892-1.pdf (accessed 28 April 2017).
} 
sels Capital Region. Policy makers should bear in mind that every asbestos-related death can be avoided. This study shows Belgium has already paid a heavy price for its indolence. It is high time for the safe and swift removal of asbestos from the whole of Belgian society.

A key strength of the present study is the availability of annual trade data for Belgium and Luxembourg. Our results reveal that the peak of Belgian asbestos consumption was actually almost 30,000 tonnes higher than previously reported in the us Geological Survey. ${ }^{107}$ We found higher asbestos consumption levels per capita in this study than those reported earlier by Nawrot et al. ${ }^{108}$ For the first time, we also have an indication of the amount and the types of asbestos used in Belgium. The type of asbestos was inferred from information about deposits in the import countries. Although small variation may occur due to transit activities, we believe our overall interpretation is accurate. Our findings complement international evidence on the consequences of asbestos use on population health. ${ }^{109}$ Belgium and 62 other countries have banned asbestos but the implementation of a global asbestos ban remains a long and difficult task. ${ }^{110}$ In light of the availability of safe and cost-effective alternatives, we urge country officials to prohibit asbestos extraction and manufacturing.

\section{About the authors}

Laura Van den Borre (1989) studied Sociology at the Vrije Universiteit Brussel (vUB). She is currently a PhD fellow of the Research Foundation-Flanders (FWo) at the research group Interface Demography of the Vrije Universiteit Brussel where she studies the impact of asbestos on mortality in Belgium.

E-mail: Laura.Van.den.Borre@vub.be

Patrick Deboosere (1951) holds a Master degree in Political Science and a PhD in Sociology. He was director of Interface Demography (ID) at the Vrije Univer-

107 Virta, Worldwide asbestos supply.

108 Nawrot et al., 'Belgium: Historical champion in asbestos consumption'.

109 R.-T.Lin etal.,'Ecological association between asbestos-related diseases and historical asbestos consumption: An international analysis', Lancet 369 (2007) 844-849, DOI: 10.1016/So140-6736(o7)6o412-7; L. Stayner, L.S. Welch and R. Lemen, 'The worldwide pandemic of asbestos-related diseases', Annual Review of Public Health 34 (2013) 205-216, DoI: 10.1146/annurev-publhealth-031811-124704.

110 Laurie Kazan-Allen, 'Current asbestos bans and restrictions (Revised 8 July 2017)', International Ban Asbestos Secretariat, 2017, http://www.ibasecretariat.org/alpha_ban_list.php (accessed 28 April 2017). 
siteit Brussel (VUB). He taught demography and research methods at the vUB and also lectured at the School for Public Health of the Université Libre de Bruxelles (ULB). He continues to contribute to ID in his area of research: population studies with a focus on population health, ageing and socio-economic differentials in mortality and health.

E-mail: Patrick.Deboosere@vub.be 